\title{
Os saberes e a trama do ensino de Biologia Celular no nível médio
}

\author{
Knowledge forms and the plot of Cell Biology \\ teaching in high school
}

\author{
Ana Flavia Vigario ${ }^{1}$. https://orcid.org/0000-0002-8409-3376 \\ Graça Aparecida Cicillini ${ }^{2}$. https://orcid.org/0000-0003-1866-3761
}

\begin{abstract}
Resumo: Neste trabalho buscamos compreender como ocorre o ensino de Biologia Celular nas escolas públicas de ensino médio, visto que o conteúdo é necessário para a compreensão da vida. A pesquisa, de natureza qualitativa, utilizou diferentes instrumentos e metodologias, tais como questionários, cursos de formação continuada, acompanhamento da prática pedagógica e grupo focal. Analisamos os questionários e as falas de professores/as e alunos/as, triangulando as informações. Foi possível verificar que a maior parte dos/as estudantes concebia célula como estrutura microscópica, apresentava dificuldade em diferenciar célula vegetal e animal e abordava os conteúdos isolando a morfologia da fisiologia celular. Nas concepções dos/as docentes, muitas vezes semelhantes às dos/as educandos/as, também havia distorções conceituais. Assim, na prática pedagógica reflexiva, o/a professor/a deve trabalhar os conteúdos de Biologia Celular, de modo a torná-los mais significativos à aprendizagem dos/as discentes na construção diária da práxis e na ressignificação do conhecimento.
\end{abstract}

Palavras-chave: Ensino de biologia celular. Ensino médio. Conhecimento. Formação de professores.

\begin{abstract}
The purpose of this paper is to explain how the teaching of Cell Biology occurs in public high schools since the subject is essential to understand life. This is a qualitative study, in which various instruments and methodologies were used, such as questionnaires, continuing education courses, the monitoring of pedagogical practice, and focus groups. The questionnaires and the speech of teachers and students were analyzed through data triangulation. It was possible to observe that most students understood the cell as a microscopic structure; they expressed difficulty in distinguishing plant cells from animal cells; and they approached contents isolating morphology from cell physiology. The teachers' conceptions, were often similar to those of the students, showed conceptual distortions. Therefore, in reflexive pedagogical practice, the teacher must work with Cell Biology topics in order to make them more meaningful to students' learning in the daily development of praxis and knowledge resignification.
\end{abstract}

Keywords: Cell biology teaching. Secondary school. Knowledge. Teacher training.

\footnotetext{
${ }^{1}$ Universidade Federal de Goiás (UFG), Departamento de Ciências Biológicas, Catalão, GO, Brasil. E-mail: afvigario@ufg.br

${ }^{2}$ Universidade Federal de Uberlândia (UFU), Faculdade de Educação, Uberlândia, MG, Brasil.
} 


\section{O ensino de Biologia Celular em nível médio no Brasil}

Entendemos a sala de aula como um espaço dinâmico no qual seus atores - professo$\mathrm{res} /$ as e alunos/as - vivenciam a articulação contínua entre currículo e conhecimento, em um cenário sócio-histórico permeado por conflitos políticos e econômicos em nível local e global. Assim é preciso compreender, como objeto de estudo desta pesquisa, o campo disciplinar da Biologia como um dos fatores imbricados na estruturação da educação básica. Tendo por base a Biologia Celular como um dos componentes biológicos curriculares, interessa-nos verificar como a temática é abordada no nível médio de ensino, partindo da pesquisa desenvolvida por Vigário (2017), cujo objetivo era discutir o cenário do ensino de Biologia Celular composto por conhecimentos específicos, metodologias de ensino e formação docente.

Goodson (2012) afirma que a Biologia, como matéria escolar, buscou o status acadêmico por meio da aceitação do controle de pesquisadores das universidades sobre ela. Diante desse domínio, a Biologia ainda recebeu, no século XX, no período entre as guerras, a influência da visão utilitária de crescimento para abranger outras áreas de importância econômica, como a indústria farmacêutica, a medicina, a agricultura, a pesca e a exploração mineral.

A educação com viés científico se firmou na década de 1960, com o objetivo de formar cientistas e estar presente nos diferentes níveis da educação básica, como espelho da formação em nível superior. Posteriormente, com a Lei 5.692, de 1971 (BRASIL, 1971), a educação nas escolas secundárias se voltou à formação para o trabalho, impactando os currículos, com vistas à formação profissionalizante.

Na década de 1970 houve o movimento de criação da disciplina de Ciências Físicas e Biológicas, na expectativa de reunir conceitos provenientes de várias áreas do conhecimento científico (WORTMANN, 2003), como da Física, da Química, da Biologia, entre outras. A formação acadêmica para esse componente curricular acontecia de forma fragmentada, em áreas individualizadas da Ciência, algo visto como empecilho para a unificação de tais disciplinas no ensino secundário.

No contexto dos anos 1980:

Diversos estudos passaram a indicar as possíveis contribuições da ciência na construção de uma sociedade verdadeiramente democrática e integradora, que pudesse superar as novas expressões do elitismo e da fragmentação social. A crítica sobre a dependência cultural pretendeu revolucionar a produção científica e tecnológica e a percepção de suas relações com a sociedade, contrariamente ao esforço intelectual dos anos 1960 e 1970, que se desenvolveu rumo a um conformismo quanto ao papel social dessas atividades. [...]. O questionamento dos ideais de cientificidade, que impõem à ciência critérios e finalidades de caráter objetivo, neutro e descontextualizado, passou a fazer parte de estudos que procuravam mostrar as relações existentes entre a ciência, a tecnologia e a sociedade (estudos CTS) (NASCIMENTO; FERNANDES; MENDONÇA, 2010, p. 240). 
Após a publicação da Lei de Diretrizes e Bases da Educação Nacional, Lei 9.394, de 1996 (BRASIL, 1996), surgiram outros documentos para nortear a educação nacional, tais como os Parâmetros Curriculares Nacionais para o ensino fundamental, os Temas Transversais e as Orientações/Diretrizes Curriculares para o ensino médio.

No campo disciplinar, houve uma disputa de espaço curricular entre as diferentes áreas que compõem as Ciências Biológicas e com outros campos do conhecimento, como Química, Física e Matemática (WORTMANN, 2003), com vistas à formação integral em Biologia e à autonomização das Ciências Biológicas (GOODSON, 2012; SELLES; FERREIRA, 2005). Dessa forma, as diferentes subáreas do conhecimento biológico - Anatomia, Biologia Celular, Botânica, Ecologia, Fisiologia, Genética e Zoologia - conquistaram espaços curriculares, reafirmando as fronteiras entre seus conhecimentos. Consequentemente, o perfil fragmentado dos saberes da Biologia está representado tanto nos currículos da educação básica como nos materiais didáticos, o que reafirma a natureza hegemônica da academia.

É evidente que a Biologia Celular permanece nos currículos da educação básica e do ensino superior mais pela força acadêmica do que pela natureza interdisciplinar e pela fluidez em conduzir a construção do conhecimento sobre a vida e os seres vivos. Todavia, mesmo ao constatarmos tal fato no currículo disciplinar da educação básica, entendemos a importância da Biologia Celular como forma de transcender a fragmentação curricular das áreas e dos conteúdos e adentrar uma Biologia do perceptível, vivenciado, bem como da construção de significados sobre a diversidade da vida. A Biologia Celular é a ponte para a compreensão dos fenômenos orgânicos dos seres vivos e suas relações com o ambiente, e, como afirma Rodríguez Palmero (2000, p. 1, tradução nossa): “a célula é um conceito chave na compreensão do conhecimento biológico". Por tais motivos, lançamo-nos a essa caminhada.

Em termos curriculares constatamos que a Biologia Celular se apresenta no ensino médio como conteúdo inicial nos Parâmetros Curriculares Nacionais, no currículo-referência dos estados de Goiás e de Minas Gerais e na maioria dos livros didáticos desse nível de ensino. Por isso, justificamos a importância de compreender o tema para o desenrolar de uma rede de assuntos das Ciências Biológicas, muitas vezes iniciando no nível micro de conteúdos para depois perpassar o macroscópico. Sendo assim, torna-se essencial esclarecer como os documentos nacionais que delineiam o currículo abordam a Biologia Celular para o nível médio de ensino.

Nos Parâmetros Curriculares Nacionais para o Ensino Médio (PCNEM) (BRASIL, 1999), o conteúdo de Biologia Celular se fundamenta na Citologia, tratando da diversidade da vida e do funcionamento celular nos processos metabólicos; da síntese proteica, do material genético, da hereditariedade e da divisão celular; dos fenômenos físico-químicos que ocorrem no interior das células; e da teoria celular. Esse documento, desenvolvido logo após a Lei 9.394, de 1996, passou por revisão e reelaboração em 2002, quando foi publicado como orientação curricular complementar aos PCN, com a denominação PCN + EM. De acordo com ele, o desafio é:

Organizar o conhecimento a partir não da lógica [temporal] que estrutura a ciência, mas de situações de aprendizagem que tenham sentido para o aluno, que lhe permitam adquirir um instrumental para agir em diferentes contextos e, principalmente, em situações inéditas de vida. (BRASIL, 2002, p. 33). 
Nesse sentido, compreender os currículos estaduais de Goiás e Minas Gerais, onde esta pesquisa foi desenvolvida, é relevante para a discussão da Biologia Celular com os/as professores/as desses dois estados que frequentaram os cursos de formação continuada.

Em Minas Gerais, a proposta curricular de Biologia está estruturada em quatro temas: teia da vida (ecossistema), história da vida na terra (população), linguagens da vida (organismo) e corpo humano e saúde (célula). A escolha dessas temáticas se justifica por:

\footnotetext{
- $\quad$ Possibilitarem a integração da Biologia, Física, Química e Matemática, propiciando um tratamento integrado dos temas das ciências da natureza e matemática.

- $\quad$ Ponderarem as ideias que organizam o pensamento biológico.

- $\quad$ Instrumentalizarem o estudante no estabelecimento de relações mais complexas entre as diversas áreas do conhecimento biológico, principalmente ao incorporar os níveis de organização dos sistemas vivos, como ecossistemas, populações, organismos e células.

- $\quad$ Possibilitarem o tratamento recursivo de algumas ideias-chave da Biologia (MARTINS et al., 2006, p. 16).
}

Em Goiás, o currículo utilizado até 2011 continha a seguinte organização: $1^{\circ}$ ano: ecologia, origem da vida, características dos seres vivos, metabolismo e histologia; $2^{\circ}$ ano: classificação dos seres vivos e fisiologia animal e vegetal; $3^{\circ}$ ano: reprodução e desenvolvimento embrionário humano, genética e evolução (FIALHO, 2016, p. 8). Entretanto, o currículo-referência do estado, criado e implementado em 2012, trouxe uma nova estruturação e distribuição de conteúdo: $1^{\text {a }}$ série: origem da vida e identidade dos seres vivos; $2^{\mathrm{a}}$ série: transmissão da vida, manipulação gênica e ética, evolução e ecologia dos seres vivos; $3^{a}$ série: diversidade da vida (GOIÁS, 2012). Segundo essa proposta, a Biologia Celular deveria estar em grande parte dos conteúdos do ensino médio.

Ao analisar esses conteúdos, não vemos muitas alterações em relação aos PCN. Porém, no cotidiano das salas de aula e na conversa com os/as professores/as, percebemos a insatisfação deles/as com a configuração curricular (FIALHO, 2016). A trama dinâmica do embate entre currículo, materiais didáticos e professores, bem como a formação destes, transparece como peça do processo de ensino e aprendizagem. Convém salientar que outros meandros dessa proposta curricular e da rede em que está envolvida serão desvelados neste trabalho, como a rigidez da distribuição bimestral dos conteúdos, as Avaliações Dirigidas Amostrais (ADA) e as faces da prática pedagógica.

\section{A formação docente e a prática pedagógica}

Investigações sobre os saberes docentes buscam tratar da atividade profissional como referência no campo das situações de ensino e aprendizagem para a formação docente (RIBEIRO, 2008). A docência se constitui em uma dinâmica dialética, manifestando o saber profissional em diferentes níveis e naturezas, tais como saberes da experiência, do conhecimento, curriculares, disciplinares e pedagógicos (PIMENTA, 1999; TARDIF; LESSARD; LAHAYE, 1991). 
De fato, pensar a sala de aula em sua multiplicidade de possibilidades se torna imprescindível para repensar o processo de ensino e aprendizagem, tomando a estrutura organizacional desse processo como ponto de partida na perspectiva da ação docente envolvida. O contexto dessa formação tem sido influenciado pelo movimento da profissionalização docente, o qual visa ao desenvolvimento sistemático da profissão.

Para compreender o contexto da formação docente, Libâneo (2004, p. 5) declara que:

Ante às necessidades educativas presentes, a escola continua sendo lugar de mediação cultural, e a pedagogia, ao viabilizar a educação, constitui-se como prática cultural intencional de produção e internalização de significados para, de certa forma, promover o desenvolvimento cognitivo, afetivo e moral dos indivíduos. O modus faciendi dessa mediação cultural, pelo trabalho dos professores, é o provimento aos alunos dos meios de aquisição de conceitos científicos e de desenvolvimento das capacidades cognitivas e operativas, dois elementos da aprendizagem escolar interligados e indissociáveis.

Desse modo, devemos discutir a formação de professores/as, com a finalidade de compreender a habilidade de organização do trabalho pedagógico como fator ímpar no ensino de Biologia. Contudo, não podemos perder de vista a dificuldade dos/as docentes em sair do espontaneismo, da criação de atividades pela simples reprodução de conceitos predefinidos, sabendo também que a habilidade de planejamento não surge de maneira despretensiosa. Segundo Ribeiro (2008), o processo de formação dos/as professores/as para planejar situações de ensino e aprendizagem precisa fazer parte da profissionalização docente.

Nesse entremeio, as experiências vividas pelos sujeitos constituem a base da aprendizagem, o sistema que integra o eixo de crescimento das atitudes e significados, além de gerarem as relações afetivas que predispõem o sujeito à consolidação do desenvolvimento intelectual. Partindo do pressuposto de que o processo de ensino e aprendizagem ocorre por meio de um conjunto intrínseco de ações inter-relacionadas, saindo da passividade da transmissão do conteúdo e almejando a construção e o desenvolvimento de estruturas cognitivas concretas, devemos dar atenção especial à união entre o conhecimento científico e os fatos cotidianos, problematizando o saber. Nesse intuito, a problematização subsidia o caráter transdisciplinar do saber, o que promove vínculos e cria significados que efetivarão a aprendizagem.

Ao compreendermos a tríade prática pedagógica/processo de ensino e aprendizagem/ construção do conhecimento como uma dinâmica de interação entre os sujeitos, professores/ as e alunos/as, há, nessa relação, a base do desenvolvimento intelectual no contexto escolar. Assim, podemos inferir que tal cenário deveria ser profícuo para a observação, o planejamento e a execução de práticas pedagógicas voltadas à qualidade de tal processo. Nessa perspectiva, discutir currículo, metodologias de ensino e recursos pedagógicos contribui significativamente para repensar a prática pedagógica.

Observamos, ainda, que fatores como baixo salário, falta de condições de trabalho, indisciplina em sala de aula, desgastes físicos e mentais da profissão, dentre outros dificultam o emprego de metodologias diferenciadas no ensino e levam à adoção do trio quadro-giz-livro como o centro estático que constrange o processo de ensino e aprendizagem. Entretanto, não é tolerável permanecer alheio a esse processo, e, em se tratando da formação de professores/as, é 
necessário, com urgência, deixar explícitas tais barreiras e caminhar rumo à transposição delas, almejando atingir uma formação plena dos/as licenciandos/as e licenciados/as, conscientes de seu papel como mediadores da construção do conhecimento, prontos para encarar a realidade e ultrapassar as limitações que forem impostas.

Segundo Cicillini (2004), ao analisar o processo de formação de professores/as, é possível determinar dois grupos diferenciados de saber: o saber de formação acadêmica - incluindo o saber da disciplina e o pedagógico - e o saber originado da docência - incorporando o cotidiano escolar, os saberes do currículo e o conhecimento biológico. Podemos inferir que, diariamente, são produzidas experiências nas quais o/a docente desenvolve saberes específicos e propõe a alteração do perfil profissional, passando de mero/a reprodutor/a de informações a produtor/a de conhecimentos.

Ensinar e aprender não são tarefas fáceis, principalmente quando é preciso partir da abstração sobre um assunto para chegar à concretização de um conceito ou processo. Como exemplos, podemos citar o ensino de Química (ROCHA; CAVICCHIOLI, 2005), que tem como base o conhecimento sobre o átomo em sua complexidade abstrata; e o ensino da Biologia, voltado ao conhecimento sobre as células (embora visíveis ao microscópio, ainda são abstratas) (BASTOS, 1992; RODRÍGUEZ PALMERO, 1997).

Rodríguez Palmero (2000) assevera que o conceito de célula e seus desdobramentos fazem parte de um corpo do conhecimento científico complexo introduzido pela escola. Esse fato evidencia que podem ocorrer distorções conceituais na tentativa de realizar a transposição didática desse conteúdo, que perde sua essência quando passa a ser tratado com caráter meramente conceitual e informativo. Além disso, essa autora (RODRÍGUEZ PALMERO, 2000, 2003; RODRÍGUEZ PALMERO; MOREIRA, 2002) e até mesmo outros estudiosos (GRAY et al., 2012) ressaltam a necessidade de desmistificar conceitos e processos celulares como base para entender o funcionamento do próprio corpo e dos outros seres vivos.

Nesse ínterim, devemos discutir um mundo microscópico ou submicroscópico que está presente na vida de qualquer ser vivo, cuja importância é necessária para a compreensão da vida.

\section{Caminhos da pesquisa}

Para o desenvolvimento deste trabalho, inicialmente realizamos uma triagem das unidades escolares do município de Catalão, estado de Goiás (GO), com o escopo de identificar todos os estabelecimentos públicos estaduais de ensino médio. Das dez escolas encontradas, selecionamos três, as quais recebiam os/as discentes estagiários/as do curso de licenciatura em Ciências Biológicas. Aplicamos aos alunos dos três anos desse nível educacional - a maioria do turno matutino e com faixa etária média de 17 anos -, um questionário contendo sete questões, sendo cinco abertas e duas fechadas. As questões abertas tinham o objetivo de conhecer as concepções de célula dos/as estudantes, com vistas à continuidade da pesquisa. Obtivemos, como retorno, 163 questionários respondidos provenientes de 11 turmas.

Por meio da análise de conteúdo, segundo Bardin (2011), em se tratando das concepções de células dos/as alunos/as provenientes dos questionários, planejamos dois cursos de formação para professores/as de Ciências e Biologia, preferencialmente de ensino médio. O curso, denominado Desafios no ensino de biologia, foi realizado em duas edições não simultâneas - uma 
em Catalão, GO e outra em Uberlândia, MG - e pretendeu implementar a formação continuada e reflexiva sobre o ensino de Biologia Celular, além de articular teoria e prática pedagógica.

Os cursos aconteceram em encontros quinzenais aos sábados, com oito horas de duração, totalizando 60 horas de atividades. Essa formação foi oferecida nas dependências da Universidade Federal de Goiás (UFG) e da Universidade Federal de Uberlândia (UFU), utilizando os recursos disponíveis nessas instituições e recebendo apoio do Conselho Nacional de Desenvolvimento Científico e Tecnológico (CNPq). Professores/as de municípios adjacentes também compareceram aos cursos.

Posteriormente, acompanhamos a prática docente de um professor de ensino médio que participou do curso de formação em Catalão, observando a maioria de suas aulas de Biologia em uma turma de $1^{a}$ série, durante o ano letivo de 2016. Ademais, tivemos reuniões semanais e/ou quinzenais para refletir sobre as dimensões do conteúdo tratado, as metodologias e as formas de avaliação. Esse momento da pesquisa foi consequência da interação entre as pesquisadoras e o professor-colaborador no contexto de sua prática docente, ao discutir e revisitar a Biologia Celular, em especial a Morfologia e a Fisiologia Celular, no processo de ensino e aprendizagem.

No decorrer do curso de formação na cidade de Uberlândia, estado de Minas Gerais (MG), havia a necessidade de realizar um grupo focal, com o objetivo de complementar as informações registradas e esclarecer algumas questões que surgiram desde a coleta de dados com os questionários até os cursos de formação e a observação da prática pedagógica. No período de realização da pesquisa utilizamos, como forma de registro de informações, questionários, gravações de áudio e fotografias. A identificação dos/as participantes se deu por meio de nomes fictícios, com a intenção de preservar identidades.

O grupo focal (GATTI, 2005) sistematiza questões apresentadas a um grupo específico, como uma entrevista sistematizada ou a discussão em grupo, com o objetivo de discutir em profundidade, ou com maior riqueza de detalhes, alguns pontos previamente selecionados na pesquisa. Durante essa atividade, foi possível acessar as reações e os conhecimentos dos participantes por meio da manifestação de sentimentos, comportamentos e concepções que poderiam subsidiar a investigação. Dessa forma, os posicionamentos que afloraram no grupo focal foram imprescindíveis para o embasamento deste estudo, uma vez que eles revelaram aspectos da prática docente que não haviam aparecido nas etapas anteriores, a exemplo das percepções individuais sobre a formação docente, das fragilidades e limitações pessoais na compreensão do conhecimento científico e sua relação com a práxis.

Os dados coletados por meio de questionários, transcrição de áudios, observação da prática pedagógica e grupo focal foram submetidos à análise qualitativa, iniciada com a categorização das respostas dos/as participantes nos questionários. Em seguida, analisamos o conteúdo das falas de alunos/as e professores/as nas etapas da pesquisa em consonância com as diretrizes de Bardin (2011), seguido da triangulação dos dados e métodos, buscando entrelaçar a literatura pertinente e a práxis.

Para executarmos a análise de conteúdo, utilizamos as três premissas definidas por Bardin (2011): (1) pré-análise - primeira leitura de todo o material coletado, leitura exploratória e criação das categorias de análise; (2) exploração do material - leituras em profundidade, seleção dos indicadores e organização das informações coletadas; e, (3) interpretação e inferência elaboração e construção de sentidos entre os dados coletados e a literatura pertinente. 
Por fim, a triangulação de dados se iniciou tanto pelo questionário quanto pelos debates realizados no curso de formação, além de informações advindas do grupo focal. Cumpre dizer que a literatura da área de ensino de Biologia também fez parte do arcabouço teórico que subsidiou a consolidação dos resultados.

\section{O ensino de Biologia Celular e os conhecimentos mobilizados}

Procuramos desvelar eixos que formam a teia de conhecimentos sobre a Biologia Celular, a forma de ensinar tal conteúdo e a importância da formação docente. O conhecimento biológico e a rede de interações com outros saberes constituem fortes amarras entre o ensinar, $\mathrm{o}$ aprender e a prática pedagógica. Ao olharmos atentamente para a união de fatores que permeia o processo de ensino e aprendizagem, notamos os pontos de conexão e de estrangulamento nesse contexto. O conhecimento específico da Biologia Celular tem caráter abstrato, devido à dimensão microscópica da maioria das células animais e vegetais. Entretanto, o conteúdo aparece nos documentos de orientação curricular de Goiás (GOIÁS, 2012) e de Minas Gerais (MARTINS et al., 2006) e nos livros didáticos como os primeiros a serem discutidos com os/ as alunos/as do primeiro ano do ensino médio.

A maioria dos/as alunos/as de ensino médio de Catalão tinha a concepção de célula como estrutura arredondada e plana, composta por membrana, citoplasma, núcleo e algumas organelas com funções específicas. Eles/as demonstraram ter noções da dimensão microscópica das células, mas o entendimento sobre a existência de diversidade celular foi detectado em apenas um dos questionários. Equívocos quanto aos diferentes níveis de organização dos seres vivos e à compreensão de célula como unidade autônoma também foram evidentes:

\section{Células são pequenas partículas que compõem os organismos de todos seres vivos e épossivel a visualização somente pelo microscópio. [A112, grifos nossos]. Células são seres vivos que dão início à vida. [A13, grifo nosso]. \\ Células são substâncias que constituem nosso corpo; elas existem de várias maneiras e cada uma com sua característica. [A238, grifo nosso].}

O tamanho microscópico das células foi apreendido pelos/as estudantes. O que nos chamou atenção foi a designação de células enquanto seres vivos, organismos, microrganismos ou substâncias, uma vez que tais concepções revelam certa inconsistência no entendimento de outras formas de vida unicelulares ou pluricelulares. Verificamos que a compreensão de célula como substância é equivocada, pois tal conceituação pode ser oriunda do senso comum.

Muitos/as alunos/as manifestaram dificuldade com a classificação celular - animal e vegetal - e outras formas de conceituações - eucarionte e procarionte. Apesar de conhecerem termos próprios da linguagem biológica, como cromossomo, eucarioto, procarioto, célula, tecido e nomes de algumas organelas, observamos, pela análise dos questionários, certa dificuldade na classificação do tipo celular. Um dos/as estudantes comentou que um/a professor/a havia realizado uma atividade prática com visualização de células da cebola e da mucosa oral, mas ele/a se perguntava: "Célula de cebola é vegetal ou animal?” e "Célula da boca é vegetal ou animal?”.

Tais informações revelam certa desorganização de ideias do conteúdo biológico, atrelada à multiplicidade de conhecimentos e à grande quantidade de nomes científicos. França 
(2015, p. 71-72) indica alguns obstáculos para a compreensão do conceito de célula: "A natureza microscópica da célula; as figuras de células no LD [livro didático], estanques como se todas as células fossem iguais; e a dificuldade com o vocabulário técnico".

Sobre a desorganização de ideias frente à nomenclatura científica, constatamos o distanciamento entre os saberes escolares e os espontâneos que cada aluno/a constrói com base na própria vivência, divergindo significativamente do conhecimento original. Assim, esse conhecimento espontâneo sobre o fato concreto, ao se confrontar com o saber científico, de origem abstrata, não cria os significados necessários e suficientes para transformar o conhecimento espontâneo ora movido (BELTRÁN NUÑEZ, 2009). Esse conhecimento novo não foi internalizado, e seu saber prévio, espontâneo, permanece basicamente sem alteração.

Diante do exposto e da importância dos conteúdos de Biologia Celular, Rodríguez Palmero (1997, 2003) e Rocha e Silveira (2010) ressaltam a dificuldade desse estudo, tendo em vista sua complexidade, os ruídos causados pela transposição didática e o grau de abstração. Fica evidente a necessidade de, para além da aula expositiva e do apoio em livros didáticos, um aporte de outros recursos pedagógicos, a exemplo de imagens tridimensionais e atividades práticas de visualização de componentes biológicos com instrumentos específicos, como microscópios, que contribuam com o processo de ensino e aprendizagem de forma dinâmica e participativa (HECK; HERMEL, 2013; ROCHA; SILVEIRA, 2010).

O posicionamento dos/as professores/as manifesta a maneira como eles/as lidam com as características desse tema (classificações, quantidade de informações e nomenclaturas, dimensão abstrata) na prática. Os/as docentes afirmaram que o volume de informações da Biologia e a complexidade da linguagem científica devem ser alguns fatores que impulsionam a desorganização de ideias relativas ao conteúdo biológico. Além disso, eles/as se posicionaram frente a problemas encontrados nas respostas dos/as alunos/as a determinados conceitos solicitados em processos avaliativos:

\footnotetext{
Alguma coisa [algum conhecimento] está ficando. [Professora Alice, grifo nosso].

Eu acho que não está tão crítico! [Professora Sandra, grifo nosso].

Tem coisas [respostas dos/as alunos/as] absurdas? [Professora Alice, grifo nosso].
}

Expressões como essas demonstram que os/as docentes, ao concordarem com o posicionamento dos/as discentes ainda que de maneira parcial, possuem concepções similares às dos/as alunos/as ao manifestarem distorções conceituais dos conhecimentos específicos ou apenas o senso comum durante as avaliações. Nesse sentido, aspectos da formação docente, inicial ou continuada podem estar intimamente relacionados a esses resultados, como abordar as disciplinas de conteúdos específicos de forma distanciada dos componentes curriculares que tratam da prática pedagógica em cursos de licenciatura.

Somadas a isso, as políticas de governo também deixam suas marcas, ao permitirem a contratação de professores/as formados/as em cursos distintos das áreas em que atuam. Em Goiás, dos/as sete docentes que iniciaram o curso, três deles/as tinham formação inicial em outras áreas do conhecimento, como Letras, Geografia e Biomedicina. Diante disso, o professor José abordou as dificuldades em ministrar aulas de Biologia: 
Estou só aprendendo. Eu conheci célula quando fui dar aula para a $1^{a}$ série [do ensino médio]. Mas é até bom que eu vou revisando cada uma delas [os tipos de células]. Eu aprendo aqui e depois ensino na aula. Quando a gente está nessa situação e começa a aprender, a pegar o ritmo da coisa, eles te tiram [A Seduce (Secretaria de Estado da Educação de Goiás) altera o contrato do professor]. Mas eu acho difícil falar para o aluno que a célula faz parte da vida dele. [...] O bom é que eu posso integrar a Geografia, que é a minha área, em algumas questões da Biologia, como o meio ambiente. Eu acho que essas reuniões [cursos de formação] deveriam ter em todas as áreas; elas facilitam muito o nosso trabalho. Uso vídeos para mostrar o conteúdo e eu não preciso explicar. Lá tem tudo [Professor José, grifos nossos].

Essas afirmações refletem a deficiência do docente na área específica e possibilitam momentos de discussão sobre a importância da formação continuada como embasamento técnico e fortalecimento do processo de ensino e aprendizagem.

Mais especificamente, nos preocupou a postura do governo do estado de Goiás em contratar professores/as com formação diferente da área em que devem atuar. Diante disso, buscamos informações com o escritório representante da Secretaria de Estado da Educação (Seduce) de Goiás e obtivemos dados do cadastro de 61 docentes de Ciências e Biologia no município onde realizamos o curso de formação continuada. Dessa população, 29 professores/ as são formados/as em Biologia e 32, em outras áreas - oito em Pedagogia, sete em Geografia, sete em Matemática, seis em Educação Física, três em Letras e um em Química. Esses indicadores mostram o grande número de professores/as de Catalão que ocupam cargos de Ciências e Biologia, mas não possuem formação específica para tal. Durante o curso de formação continuada tivemos a oportunidade de verificar que, mesmo que tivessem graduação na área biológica, alguns/as docentes manifestavam aspectos conflitantes sobre conceitos de Biologia Celular, o que leva a noções incorretas de fenômenos biológicos.

Com base nisso, interpretamos outros dados resultantes desta pesquisa, como a dificuldade dos/as estudantes em compreender a constituição orgânica tanto micro quanto macroscópica dos organismos, a fragmentação entre Morfologia e Fisiologia Celular no ato de ensinar, a visão antropocêntrica sobre os seres vivos e a classificação da biodiversidade. Temos, nos registros subsequentes, o reforço da fragmentação do conhecimento que impossibilita o movimento entre os saberes de esferas macro e microscópicas da Morfologia e da Fisiologia:

As células realizam uma função importante tanto nos animais quanto em seres vivos, porque ajudam no funcionamento do corpo humano. [A28, grifos nossos].

Estruturas minúsculas [organelas], com diversas funções, existem em todos os seres vivos. [A106, grifo nosso].

No caso do aluno A28, a dimensão macro é representada pelo corpo humano, e a micro, pela célula. Rodríguez Palmero e Moreira (1999) discorrem sobre o fato de as representações vinculadas à estrutura e ao funcionamento celular constituírem um obstáculo epistemológico 
que inibe a compreensão e a formação de conceitos sobre a interação entre estrutura e função, além dos processos fisiológicos dinâmicos dos seres vivos, a exemplo do metabolismo. Heck e Hermel (2013) afirmam que os saberes prévios de Biologia Celular não estão consolidados ao final do ensino médio, o que se à fragmentação recorrente entre Morfologia e Fisiologia, algo identificado por Rodríguez Palmero (2003) e que distancia a célula real (estrutura dinâmica, funcional e ativa) da ideal (retratada nos livros didáticos (LD), que a abordam como modelo estático, colorido, em muitos casos, e com inúmeras organelas (A106). Batisteti, Araújo e Caluzi (2009) alegam que muitas ilustrações utilizadas nos LD não poderiam ser visualizadas na realidade por meio de um microscópio ótico escolar, devido ao poder de ampliação, ao tipo e ao plano de corte e/ou coloração.

Rodríguez Palmero (2003) também pondera que a adoção de um tipo idealizado de célula é contraproducente no âmbito do ensino e da aprendizagem, por superestimar uma fragmentação na qual a morfologia ganha realce em relação à fisiologia, aos processos celulares que ocorrem de forma integrada e à associação de atividades de diferentes organelas que, em conjunto, geram um funcionamento complexo e inter-relacionado. Em muitos casos, inclusive nesta pesquisa, verificamos que a Fisiologia é tratada como um tema à parte da Morfologia Celular, o que consequentemente hierarquiza conhecimentos, e a Fisiologia, por sua vez, não protagoniza os saberes que levariam à compreensão do funcionamento dos organismos vivos. $\mathrm{O}$ professor Pedro, em suas aulas, deu grande destaque à morfologia das células vegetais, sobretudo aos cloroplastos, e não abordou o fenômeno da fotossíntese, alegando que trabalharia o tema posteriormente. Por conseguinte, sua prática pedagógica se aproxima muito do que está disposto nos livros didáticos e na formação acadêmica em Ciências Biológicas que, tradicionalmente, traz a Morfologia, seja animal ou vegetal, separada da Fisiologia.

Noções de fisiologia celular e de vida permearam as respostas de alunos/as do ensino médio, ao diferenciarem as células pela presença ou não de movimento:

\section{A diferença entre a célula animal e a vegetal é porque a célula animal é uma célula viva, ela se mexe; a célula vegetal é morta, não mexe. [A204, grifos nossos]. \\ Ela [a célula] se move pelo nosso corpo e vai se regenerando. Quando a célula morre, por exemplo, se alguém te der um beliscão, você não sente, pois a célula está morta. [A314, grifos nossos].}

Essas afirmações nos remetem aos primeiros contatos das crianças com o reconhecimento de seres vivos e não vivos e suas relações e concepções prévias construídas no cotidiano de observação e vivência anterior aos primeiros anos do ensino fundamental. Também nos levam a pensar sobre a compreensão de vida que foi discutida em sala de aula ou a noção de vida como sendo o contrário da morte. Isso se baseia na visão da tradição cristã, pela qual "a vida seria o oposto da morte" (SILVA; ANDRADE; CALDEIRA, 2009, p. 3), ou seja, para o/a estudante, as células vivas se moveriam pelo corpo; como as células mortas não se moveriam, ficariam em um local onde não existe sensibilidade. É evidente que o entendimento distorcido do conceito de vida pode ser consequência tanto de distorções de linguagem como de simplificações ou até analogias superficiais e equivocadas acerca do conteúdo biológico no ato de ensinar. 
Rodríguez Palmero (2003, p. 238, tradução nossa) afirma que os/as estudantes de nível médio têm dificuldade de desenhar, "modelar, descrever uma célula em funcionamento, assim como relacionar as estruturas que conhecem (em termos descritivos) com seu comportamento real'. Nessa perspectiva, questionamos: como a vida é compreendida por alunos/as da educação básica? O não entendimento do conceito/funcionamento da célula (ou a distinção entre célula animal e vegetal) seria um obstáculo para compreender o corpo dos seres vivos? Quais outras dimensões do conhecimento - histórica e filosófica - permeiam o processo de ensino e aprendizagem?

Estudantes que participaram da pesquisa se referiram à falta de movimento como morte. No curso de formação, esse entendimento do binômio vida-morte foi interpretado pelos/as docentes como uma forma de pensamento reducionista dos/as alunos/as. Ao questionarmos as concepções dos/as discentes sobre vida/movimento e morte/não movimento junto aos/às professores/as, eles/as abordaram possibilidades para tais pensamentos:

\footnotetext{
A falta de movimento e sensibilidade das plantas em comparação com os animais pode ter gerado essa concepção dos/as alunos/as. [Professora Maria, grifo nosso].

Nossos alunos têm pouco conhecimento sobre os animais sésseis que habitam ambientes aquáticos, como as esponjas. [Professora Alice, grifo nosso].
}

Além do exposto, essa percepção dos/as estudantes nos levou a pensar que eles/as entendiam os animais como mais complexos que os vegetais, uma vez que eram dotados de vida e movimento. Quanto a essas concepções hierárquicas, em que a célula animal é colocada em destaque ou com vantagem em relação à vegetal, selecionamos alguns exemplos:

A célula vegetal produz clorofila, responsável pela pigmentação, e a célula animal produz energia, não produz clorofila. [A29, grifos nossos].

A [célula] vegetal só apresenta em plantas, e a animal, em seres vivos. [A317, grifo nosso].

Notamos, para além do problema de linguagem, que o/a aluno/a A29 entende que a função da clorofila é dar cor aos vegetais, tanto que os animais não a possuem. Outras noções estão imbuídas nessa concepção, como a produção e a transferência de energia, além dos fenômenos de fotossíntese e respiração celular. Depreendemos, consequentemente, que o entendimento da morfologia celular desvinculada da fisiologia celular e a percepção dos níveis micro e macroscópico do organismo e do ambiente podem gerar esse tipo de erro conceitual. $\mathrm{Na}$ afirmação feita pelo/a discente A317, observamos a inferência de que as plantas não são seres vivos, por generalizar que "a célula animal” é própria desse grupo.

Também observamos que os/as alunos/as frequentemente se referiam às suas células ou ao corpo humano. Por exemplo:

Células são as partículas que nosso corpo tem; só com uma gota de sangue podemos ver que milhares de células nos ajudam a adaptar aos lugares. [A215, grifos nossos]. 
Célula é uma pequena parte do corpo, ou seja, uma pequena estrutura que faz com que o nosso corpo se desenvolva e o sangue circule. [A122, grifos nossos].

A célula é uma estrutura que em seu centro [núcleo] está contido o DNA, responsável por "carregar" todas as informacõos sobre o indivíduo. Ela está em constante transformação, se dividindo e dando origem a novas células que formarão todas as estruturas do nosso organismo, promovendo a renovação celular. [A260, grifo nosso].

As evidências supracitadas traduzem uma visão antropocêntrica de ciência. Resultados semelhantes a esses foram encontrados por Cunha (2011, p. 58) com alunos/as de ensino médio, ao relacionarem "célula com o próprio corpo, indicando uma visão centrada nas características humanas para explicar a vida".

Nesses termos, tais constatações podem ser reflexo do processo de ensino e aprendizagem em que a formação docente, o ambiente escolar, o currículo e outras questões sociopolíticas interferem na produção do conhecimento individual e coletivo, no que se refere aos conceitos espontâneos e aos saberes escolares manifestados tanto por discentes como pelos/ as professores/as, incluindo a transposição didática. A reorganização do saber, para torná-lo ensinável, é uma etapa fundamental, como apresenta Forquin (1992, p. 32), in verbis:

A educação escolar não se limita a fazer uma seleção entre os saberes e os materiais culturais disponíveis num momento dado da sociedade. Ela deve também, a fim de os tornar efetivamente transmissíveis, efetivamente assimiláveis para as jovens gerações, se entregar a um imenso trabalho de reorganização, de reestruturação, de "transposição didática". É que a ciência do erudito não é diretamente comunicável ao aluno, tanto quanto a obra do escritor ou o pensamento do teórico. É preciso a intercessão de dispositivos mediadores, a longa paciência de aprendizagens metódicas e que não deixam nunca de dispensar as muletas do didatismo.

Segundo Chevallard (1991, p. 39):

Um conteúdo de saber que tenha sido definido como saber a ensinar, sofre, a partir de então, um conjunto de transformações adaptativas que irão torná-lo apto a ocupar um lugar entre os objetos de ensino. O "trabalho" que faz de um objeto de saber a ensinar, um objeto de ensino, é chamado de transposição didática.

Dessa forma, destacamos a relevância da transposição didática em meio ao processo de ensino e aprendizagem, a partir do pressuposto de que o conhecimento científico deve ser transformado em saber ensinável nos diferentes níveis da educação básica. Entretanto, ressaltamos a influência da formação docente e da práxis reflexiva na criação e execução de mecanismos de transposição didática do conhecimento científico, para que não ocorram erros conceituais ou uso do senso comum como único subsídio ao ensinar. 
O reflexo e os produtos da formação docente emergiram durante a realização do grupo focal, em que professores/as graduados/as discutiram sobre a formação inicial. Nesse contexto surgiram concepções diversificadas:

Pensando sobre isso [ensino de Anatomia], lá na nossa metodologia [do curso de graduação], [...] deveriam ampliar... Não é só questão da carga horária; o leque de disciplinas, a didática da ciência, como ensinar, a metodologia do ensino, nossa carga horária ainda é muito restrita. Depois a gente vai para os estágios... Então tem que se ter uma melhoria nessa carga horária, nesses enfoques metodológicos e disciplinares com relação a essa formação do professor. As nossas discussões são muito curtas na graduação. Lógico que o professor não se forma na graduação, é ao longo da vida! [...] Mas acho que deveria ter um aprofundamento maior nas questões didáticas, metodológicas de trabalhar o conteúdo. [Professora Lara, grifos nossos].

A postura dessa professora nos aproxima do que Tardif (2011, p. 36) entende como conhecimento docente, formado por um amálgama diverso/plural de saberes provenientes da formação profissional, além de conhecimentos disciplinares, curriculares e da experiência. Nesse conjunto se inserem os conhecimentos pedagógicos formados mediante o pensar sobre a prática pedagógica e sua relação com outros campos do saber. Assim, a reivindicação dessa docente por maior tempo de vivência no ambiente escolar e de sala de aula se justifica e fornece elementos para a revisão curricular dos cursos que formam professores de Biologia, com foco n a educação básica.

\section{Considerações finais}

A riqueza de informações sobre os saberes e as concepções alternativas dos/as discentes e docentes do ensino médio a serem explorados está apenas esboçada nesta pesquisa. Contudo, esperamos que seja uma amostragem bem-sucedida das potencialidades e dos desafios imbricados no desenvolvimento profissional do docente da educação básica.

Em diversos momentos, observamos que as concepções de estudantes e docentes se apresentavam muito próximas e similares. Essa situação perpassa o cerne da formação desses/ as professores/as, a qualidade dos cursos de formação e sua influência direta no processo de ensino e aprendizagem, bem como os referenciais utilizados por esses profissionais da educação, a disponibilidade de oportunidades de formação continuada ao longo do exercício profissional, os interferentes político-educacionais e curriculares na ação docente, entre outros aspectos.

Diferentes posicionamentos dos/as docentes, no que tange às concepções do corpo discente que afloraram durante a pesquisa, foram imprescindíveis para revelar outros aspectos da prática profissional, tais como as percepções individuais sobre a formação, as fragilidades e limitações pessoais na compreensão do conhecimento científico e sua relação com a prática pedagógica. Nesse sentido, a reflexão sobre a ação docente no curso de formação e no acompanhamento da prática pedagógica trouxe contribuições para tornar esses/as profissionais do 
ensino sujeitos ativos, algo fundamental no processo de ensino e aprendizagem da Biologia, proporcionando momentos profícuos ao seu desenvolvimento.

Ainda no que concerne à reflexão sobre a prática docente, esta pesquisa possibilitou vivenciar a transformação do ensino e da aprendizagem em um continuum de construção diária, em que a docência e os conhecimentos científico e escolar foram ressignificados pela evolução da avaliação permanente a respeito desse processo para um determinado contexto. Acreditamos que cada turma de alunos/as representa uma multiplicidade de possibilidades, ideias, individualidades, tempos e espaços.

Ao refletirmos sobre os resultados ora apresentados é possível, concordando com Cicillini (2012), levantar aspectos para reformular as políticas de formação docente, sobretudo no que diz respeito à formação inicial para a licenciatura, com foco no trabalho docente:

- $\quad$ incluir, como eixos estruturantes dessa formação, os saberes pedagógicos e o diálogo permanente com as redes de ensino;

- $\quad$ adicionar a reflexão sobre as representações sobre professor no processo de formação docente;

- $\quad$ incorporar, nas políticas de formação, a valorização do trabalho do professor, expressa por condições de remuneração e de atuação junto à diversidade de alunos matriculados nas escolas; e

- $\quad$ estimular a reflexão sobre aspectos afetivos envolvidos na formação docente.

Mudanças dessa natureza podem auxiliar o processo formativo dos futuros professores. Isso ocorre no sentido da articulação de saberes complexos relacionados ao trabalho docente, do desenvolvimento profissional e do fortalecimento da opção por se constituir professor.

Destarte, esperamos que as análises decorrentes desta pesquisa contribuam para a discussão sobre o ensino de Biologia Celular e a formação de professores de forma reflexiva. É preciso propor alternativas para aprimorar a prática pedagógica dos/as docentes e otimizar a qualidade do ensino e da aprendizagem de conteúdos da área da Biologia, principalmente no que se refere à Biologia Celular.

\section{Agradecimentos}

Aa autoras agradecem ao Ministério da Ciência, Tecnologia, Inovações e Comunicações (MCTIC) e ao Conselho Nacional de Desenvolvimento Científico e Tecnológico (CNPq).

\section{Referências}

BARDIN, L. Análise do conteúdo. São Paulo: Edições 70, 2011.

BATISTETI, C. B.; ARAÚJO, E. S. N.; CALUZI, J. J. As estruturas celulares: o estudo histórico do núcleo e sua contribuição para o ensino de biologia. Filosofia e História da Biologia, São Paulo, v. 4, p. 17-42, 2009. Disponível em: http://www.abfhib.org/FHB/ FHB-04/FHB-v04-01-Caroline-Batisteti-et-al.pdf. Acesso em: 21 fev. 2019. 
BASTOS, F. O conceito de célula viva entre os alunos de segundo grau. Em Aberto, Brasília, ano 11, n. 55, p. 63-69, 1992. Disponível em: http://emaberto.inep.gov.br/index.php/ emaberto/article/view/1860/1831. Acesso em: 21 fev. 2019.

BELTRÁN NUÑEZ, I. B. Vygotsky, Leontiev e Galperin: formação de conceitos e princípios didáticos. Brasília: Liber Livro, 2009.

BRASIL. Lei no 5.692, de 11 de agosto de 1971. Fixa diretrizes e bases para o ensino de $1^{\circ}$ e $2^{\circ}$ graus e dá outras providências. Diário Oficial da União, Brasília, 12 ago. 1971.

Disponível em: http://www.planalto.gov.br/ccivil_03/leis/L5692.htm. Acesso em: 30 mar. 2017.

BRASIL. Lei no 9.394, de 20 de dezembro de 1996. Estabelece as diretrizes e bases da educação nacional. Diário Oficial da União: seção 1, Brasília, DF, p. 27.833, 23 dez. 1996.

BRASIL. Ministério da Educação e do Desporto. Parâmetros curriculares nacionais: ensino médio. Brasília: MEC, 1999.

BRASIL. Ministério da Educação e do Desporto. PCNs + ensino médio: orientações educacionais complementares aos parâmetros curriculares nacionais. Brasília: MEC, 2002.

CHEVALLARD, Y. La transposición didáctica: del saber sabio al saber enseñado. Buenos Aires: Aique, 1991.

CICILLINI, G. A. Conhecimento científico e conhecimento escolar: a cultura da sala de aula e o saber evolutivo sobre os vegetais. In: ROMANOWSKI, J. P.; MARTINS, P. L. O.; JUNQUEIRA, S. R. A. (org.). Conhecimento local e conhecimento universal: a aula, aulas nas ciências naturais e exatas, aulas nas letras e artes. Curitiba: Champagnat, 2004. p. 161-174.

CICILLINI, G. A. Constituindo-se professor(a): os significados das representações sobre professor(a) e dar aula na história de discentes de ciências físicas, químicas e biológicas. 2012. Relatório (Pós-doutorado em Educação) - Fundação Carlos Chagas, São Paulo, 2012.

CUNHA, K. M. C. B. O ensino e a aprendizagem significativa da célula no contexto da disciplina biologia do primeiro ano do ensino médio em uma escola pública do Rio de Janeiro. 2011. Dissertação (Mestrado em Ensino em Biociências e Saúde) - Instituto Oswaldo Cruz, Rio de Janeiro, 2011.

FIALHO, C. G. O currículo referência do estado de Goiás e suas mudanças para o ensino de ciências e biologia. Itinerarius Reflectionis, Jataí, v. 12, n. 1, p. 1-13, 2016. Disponível em: https://www.revistas.ufg.br/rir/article/view/37135. Acesso em: 21 fev. 2019.

FORQUIN, J.-C. Saberes escolares, imperativos didáticos e dinâmicas sociais. Teoria e Educação, Porto Alegre, n. 5, p. 28-49, 1992.

FRANÇA, J. A. A. Ensino-aprendizagem do conceito de "célula viva": proposta de estratégia para o ensino fundamental. 2015. Dissertação (Mestrado em Ensino de Ciências) Universidade de Brasília, Brasília, 2015.

GATTI, B. Grupo focal na pesquisa em ciências sociais e humanas. Brasilia, DF: Liber Livro, 2005. 
GOIÁS. Secretaria de Estado da Educação. Currículo referência da rede estadual de educação de Goiás. Goiânia: SEE, 2012.

GOODSON, I. F. Currículo: teoria e história. 13. ed. Petrópolis: Vozes, 2012.

GRAY, R.; GRAY, A.; FITE, J. L.; JORDAN, R.; STARK, S.; NAYLOR, K. A simple microscopy assay to teach the processes of phagocytosis and exocytosis. CBE Life Sciences Education, Bethesda, v. 11, n. 2, p. 180-186, 2012. Disponível em: https://www.lifescied. org/doi/10.1187/cbe.11-07-0060. Acesso em: 21 fev. 2019.

HECK, C. M.; HERMEL, E. E. S. A célula em imagens: uma análise dos livros didáticos de ciências no ensino fundamental. In: ENCONTRO REGIONAL SUL DE ENSINO DE BIOLOGIA, 6., 2013, Santo Ângelo. Anais [...]. Santo Ângelo, RS: Universidade Regional Integrada do Alto Uruguai e das Missões, 2013.

LIBÂNEO, J. C. A didática e a aprendizagem do pensar e do aprender: a teoria histórico-cultural da atividade e a contribuição de Vasili Davydov. Revista Brasileira de Educação, Rio de Janeiro, n. 27, p. 5-24, 2004. DOI: https://doi.org/10.1590/S141324782004000300002.

MARTINS, C. M. C.; TOLEDO, M. I. M.; SANTOS, M. B. L.; BRAGA, S. A. M. Proposta curricular: biologia ensino médio. [Belo Horizonte: Secretaria de Estado da Educação, 2006]. Disponível em: http://crv.educacao.mg.gov.br/sistema_crv/banco_objetos_ crv/\%7B34F10634-1508-447C-BC5A-3E45DC2D7A01\%7D_biologia.pdf. Acesso em: 30 abr. 2017.

NASCIMENTO, F.; FERNANDES, H. L.; MENDONÇA, V. M. O ensino de ciências no Brasil: história, formação de professores e desafios atuais. Revista HISTEDBR On-line, Campinas, v. 10, n. 39, p. 225-249, 2010. DOI: https://doi.org/10.20396/rho. v10i39.8639728.

PIMENTA, S. G. Formação de professores: identidade e saberes da docência. In: PIMENTA, S. G. (org.). Saberes pedagógicos e atividade docente. São Paulo: Cortez, 1999. p. 15-34.

RIBEIRO, R. P. O processo de aprendizagem de professores do ensino fundamental: apropriação da habilidade de planejar situações de ensino de conceitos. 2008. Tese (Doutorado em Educação) - Universidade Federal do Rio Grande do Norte, Natal, 2008.

ROCHA, M. P.; SILVEIRA, D. T. O que eles sabem sobre as células? Revista da SBENBIO, Fortaleza, n. 3, p. 876-882, 2010.

ROCHA, J. R. C.; CAVICCHIOLI, A. Uma abordagem alternativa para o aprendizado dos conceitos de átomo, molécula, elemento químico, substância simples e substância composta nos ensinos fundamental e médio. Química Nova na Escola, São Paulo, n. 21, p. 29-33, maio 2005. Disponível em: http://qnesc.sbq.org.br/online/qnesc21/v21a06.pdf. Acesso em: 21 fev. 2019. 
Vigario, A. F; Cicillini, G. A.

RODRÍGUEZ PALMERO, M. L. Revisión bibliográfica relativa a la enseñanza de la biología y la investigación en el estudio de la célula. Investigações em Ensino de Ciências, Porto Alegre, v. 5, n. 3, p. 237-263, set. 2000.

RODRÍGUEZ PALMERO, M. L. Revisión bibliográfica relativa a la enseñanza/aprendizaje de la estructura e del funcionamiento celular. Investigações em Ensino de Ciências, Porto Alegre, v. 2, n. 2, p. 123-149, 1997.

RODRÍGUEZ PALMERO, M. L. La célula vista por el alumnado. Ciência $\boldsymbol{\&}$

Educação, Bauru, SP, v. 9. n. 2, p. 229-246, 2003. DOI: https://doi.org/10.1590/S151673132003000200006.

RODRÍGUEZ PALMERO, M. L.; MOREIRA, M. A. Modelos mentales de la estructura y el funcionamiento de la célula: dos estudios de casos. Investigações em Ensino de Ciências, Porto Alegre, v. 4, n. 2, p. 121-160, 1999.

RODRÍGUEZ PALMERO, M. L.; MOREIRA, M. A. Una aproximación cognitiva al aprendizaje del concepto "célula": un estudio de caso. Revista Brasileira de Pesquisa em Educação em Ciências, Belo Horizonte, v. 3, n. 2, p. 45-58, maio/ago. 2002.

SELLES, S. E.; FERREIRA, M. S. Disciplina escolar biologia: entre a retórica unificadora e as questões sociais. In: MARANDINO, M.; FERREIRA, M. S.; AMORIM, A. C. (org.). Ensino de biologia: conhecimentos e valores em disputa. Niterói: EDUFF, 2005. p. 50-62.

SILVA, P. R.; ANDRADE, M. A. B. S.; CALDEIRA, A. M. A. A concepção de professores de biologia sobre o conceito de vida. In: ENCONTRO NACIONAL DE PESQUISA EM EDUCAÇÃO EM CIÊNCIAS (ENPEC), 7., 2009, Florianópolis. Anais [...]. Florianópolis: UFSC: Abrapec, 2009. p. 1-12.

TARDIF, M. Saberes docentes e formação profissional. Petrópolis: Vozes, 2011.

TARDIF, M.; LESSARD, C.; LAHAYE, L. Os professores face ao saber: esboço de uma problemática do saber docente. Teoria \& Educação, Porto Alegre, n. 4, p. 215-233, 1991.

VIGÁRIO, A. F. As tramas do ensino de biologia celular na educação básica: conteúdos específicos, prática pedagógica e formação de professores/as. 2017. Tese (Doutorado em Educação) - Universidade Federal de Uberlândia, Uberlândia, 2017.

WORTMANN, M. L. C. Currículo e ciências: as especificidades pedagógicas do ensino de ciências. In: COSTA, M. V. (org.). O currículo nos limiares do contemporâneo. 3. ed. Rio de Janeiro: DP\&A, 2003. p. 129-157.

Artigo recebido em 16/10/2017. Aceito em 16/09/2018.

Contato: UFG, Departamento de Ciências Biológicas, Av. Lamartine Pinto de Avelar, n. 1.120, IBIOTEC, bloco M, sala 301 Catalão, GO. CEP: 75740-020, Brasil. 